\title{
Review of some significant claimed irregularities in Scandinavian postglacial uplift on timescales of tens to thousands of years - earthquakes in Denmark?
}

\author{
S. Gregersen and P. H. Voss
}

Geological Survey of Denmark and Greenland, Ostervoldgade 10, 1350 Copenhagen K, Denmark

Correspondence to: S. Gregersen (sg@geus.dk)

Received: 6 June 2013 - Published in Solid Earth Discuss.: 16 September 2013

Revised: 12 December 2013 - Accepted: 18 December 2013 - Published: 20 February 2014

\begin{abstract}
The postglacial uplift and surrounding subsidence in Scandinavia is well described as close to regular, and the phenomenon is similar on timescales of tens, hundreds and thousands of years studied via geodesy, seismology and geology. Searches for irregularities in the form of earthquakes claimed in the scientific literature have disclosed many earthquakes right after the Ice Age, $9000 \mathrm{yr}$ ago, and some later cases for further evaluation. In a previous report, the present authors have mentioned doubts about the validity of some of the most significant claimed irregularities. In the present paper, a review is made of these significant claimed irregularities in the south-western flank of the Scandinavian postglacial uplift and subsidence via literature studies of geodetic and geological claims of earthquakes as well as discussions in the field. Geodetic observations exist for all of Scandinavia that describe the phenomenon on a scale of $10 \mathrm{~s}-100 \mathrm{~s}$ of years. Earthquake observations in seismology are of relevance in the same timescales. Geological studies of dated shore lines describe the postglacial vertical earth-surface motion in a quite different timescale of 100s-1000s of years. There is a need for integration of these observations geographically. This is happening in the various timescales in the DynaQlim project. The review finds the claims unlikely to be earthquakes concerning the following: (1) geodynamical motion in the Copenhagen area, (2) a palaeo-earthquake in Læs $\varnothing$ and (3) the recently proposed water level discrepancy in the southern part of Denmark. The assessment is less certain, but falls to improbable when concerning (4) proposed palaeo-earthquakes by Hallandsåsen in south-western Sweden.
\end{abstract}

\section{Introduction}

Our geodesist colleagues are making more and more definitive observations of the uplift pattern of Scandinavia and the surrounding subsidence. Methods are improving from levelling and sea level observations to GPS measurements nowadays. Many DynaQlim papers have over the years substantiated the pattern of vertical motion on the timescales 10 s to 100 s of years. The central parts of such a good, regular reference pattern NKG2005LU (Vestøl, 2006; Ågren and Svensson, 2007; Engsager et al. 2006, personal communication) are in the present paper displayed in Fig. 1, overlayed on the earthquake activity. This geodetic pattern in essence represents also the geological pattern of a timescale of 1000 s of years, which is established via dated beach lines in old as well as more recent data collections. De Geer gave in 1888 a summary based on geological data available at his time, shown by Mörner (1979) in a paper, where he presented his newer map with more data, but introducing some questionable assumptions on linearity. The overlapping geodetic and geological patterns more than indicate that it is the same phenomenon which uplifts Scandinavia in the timescales tens, hundreds and thousands of years. The pattern which can be well represented by a broad-scale upwelling bulge is used by other authors as data points for fitting in their theoretical modelling (e.g. Lambeck et al., 2010).

The first irregularity to be noticed in observations as well as modelling is that the uplift rate has changed drastically from very fast right after the Ice Age, $9000 \mathrm{yr}$ ago, to much slower nowadays. The second observation is that the geographical patterns satisfying the observations are very regular, which means that irregularities are noticeable and worth 
a review. Irregularities have been found and evaluated in a number of papers for Norway (e.g. Olesen et al., 2004; Bungum et al., 2010). Here it is done for Denmark.

\section{Stresses in the lithosphere of various timescales}

In previous papers the stress development after the Ice Age has been treated (e.g. Gregersen and Voss, 2010). The stress field was right after off-loading of the ice, dominated by the uplift and pressure outwards from the central parts. Later, the present situation is that the uplift is less important while stresses caused by the present lithospheric plate movements are dominating with compression in a north-west-south-east direction (Gregersen and Voss, 2009; Olesen et al., 2004; Bungum et al., 1991; Lindholm et al., 2000; Gregersen, 1992). In several papers it is argued that there is no correlation between the uplift pattern and the pattern of earthquake locations (e.g. Gregersen, 2002; Gregersen and Voss, 2009, Zoback et al., 1989; Zoback, 1992; Poutanen et al., 2009), which for all of Scandinavia is displayed in Fig. 1. Like displays of earthquake activity in other parts of the world, it does not matter much which is the time period displayed. The general pattern is the same in any time period, while details can be different. The figure shows that the earthquake activity is most concentrated along the Norwegian coast and continental margin, along the Swedish east coast, and in and around the Oslo Fjord. It is well established that the earthquake activity in Denmark is the southern limitation of the Scandinavian seismicity (Gregersen et al., 1998). And there is less earthquake activity as we go south-west in Jylland in the middle of Denmark. It is also established with good credibility that the earthquake activity is smaller in northern Germany, in Poland and in the Baltic states (e.g. Grünthal et al., 2008). In the latter areas the seismograph coverage has until recently been significantly poorer, so the information in the map is influenced by less sensitivity to small earthquakes. But there is not much doubt that the Kaliningrad events in 2004 of magnitudes just over 5 are very unusual for the coast of Poland, Russia and Lithuania (Gregersen et al., 2007). The map should be complete down to magnitude 4 .

\section{Earthquake investigations of various timescales}

Several investigations are available concerning the regional, recent earthquake activity around the south-western edge of the Fennoscandian Shield. First of all the prominent geological zone Sorgenfrei-Tornquist Zone is considered inactive, except for a small part in eastern Kattegat (e.g. Arvidsson et al. 1991; Gregersen et al. 1998). An illustration of this inactivity concerning earthquakes is shown in Fig. 2, supplementing the regional activity picture of Fig. 1. The earthquake dots in the two maps of Fig. 2 are the same, and they cover the same area. The purpose of the map without coasts and geology is to show the earthquake activity without prejudice from coast lines and geological zones. The Sorgenfrei-Tornquist Zone passes right through the middle of the illustration, but its trend can not be distinguished through earthquake activity. The Ringkobing-Fyn Ridge can not be distinguished either. This just emphasizes what has been pointed out before (e.g. Gregersen et al., 2011).

The summary of the small earthquake activity in Denmark (Figs. 1 and 2) is that it occurs not in one specific linear zone, but rather scattered in several zones in north-western Jylland and in Kattegat as well as completely unsystematic in eastern Denmark and southern Sweden (Gregersen et al. 1998). In a general sense, the seismicity pattern in Denmark shows us the irregular rheological edge zone of the stiff old Fennoscandian Shield, not as an active zone but rather as a broad area of transition from some earthquake activity in the shield north-east of the zone to quiet area south-west of the zone. In the European scale the Tornquist Zone is considered as present-day inactive, as presented in conference proceedings by Gregersen et al. (1995) and seen as lack of earthquakes in the lower right hand corner of Fig. 2, in Poland.

At least a part of Scandinavia has experienced postglacial earthquakes (e.g. Lagerbäck, 1990, 1991). These earthquakes (Fig. 1) in northern Scandinavia were caused by the Ice Age ice cap melting away within a short time. That the present-day stress regime is completely different is agreed by Mörner (2003), but additionally Mörner (2003, 2009) presents palaeo-seismological arguments on some large Swedish earthquakes further south in Sweden than those of Fig. 1. And in some cases, both in northern and southern Sweden, those earthquakes appear to be younger than $9000 \mathrm{yr}$, the time when the last ice cap melted away. Those arguments of Mörners $(2003,2009)$ are less convincing than those giving basis for the earthquake fault signatures of Fig. 1, where Mörner agrees with Lagerbäck $(1990,1991)$. An evaluation for Sweden is needed, just like that for Norway (Olesen et al., 2004). A first step is taken by the discussion concerning claim 4 of this paper.

\section{Assessment of claims in the geologic and geodetic literature of active faulting near Denmark}

The present assessment review includes both the long-term geological evidence and the short-term geodetic evidence. Additionally the assessment acknowledges the view, that the small present-day earthquake activity in Scandinavia is caused by a dominating stress field from lithospheric plate motion, supplemented by stresses from the postglacial uplift (Gregersen and Basham, 1989; Zoback et al., 1989; Gregersen, 1990 and 1992) as well as by other regional effects as lithospheric inhomogeneities (e.g. Hicks et al., 2000; Pascal and Cloetingh, 2009; Bungum et al., 2010; Olesen et al., 2012). Generalized maps of the very regular postglacial uplift of the investigated area near Denmark have recently been presented from geodetic sources (Knudsen et al. 


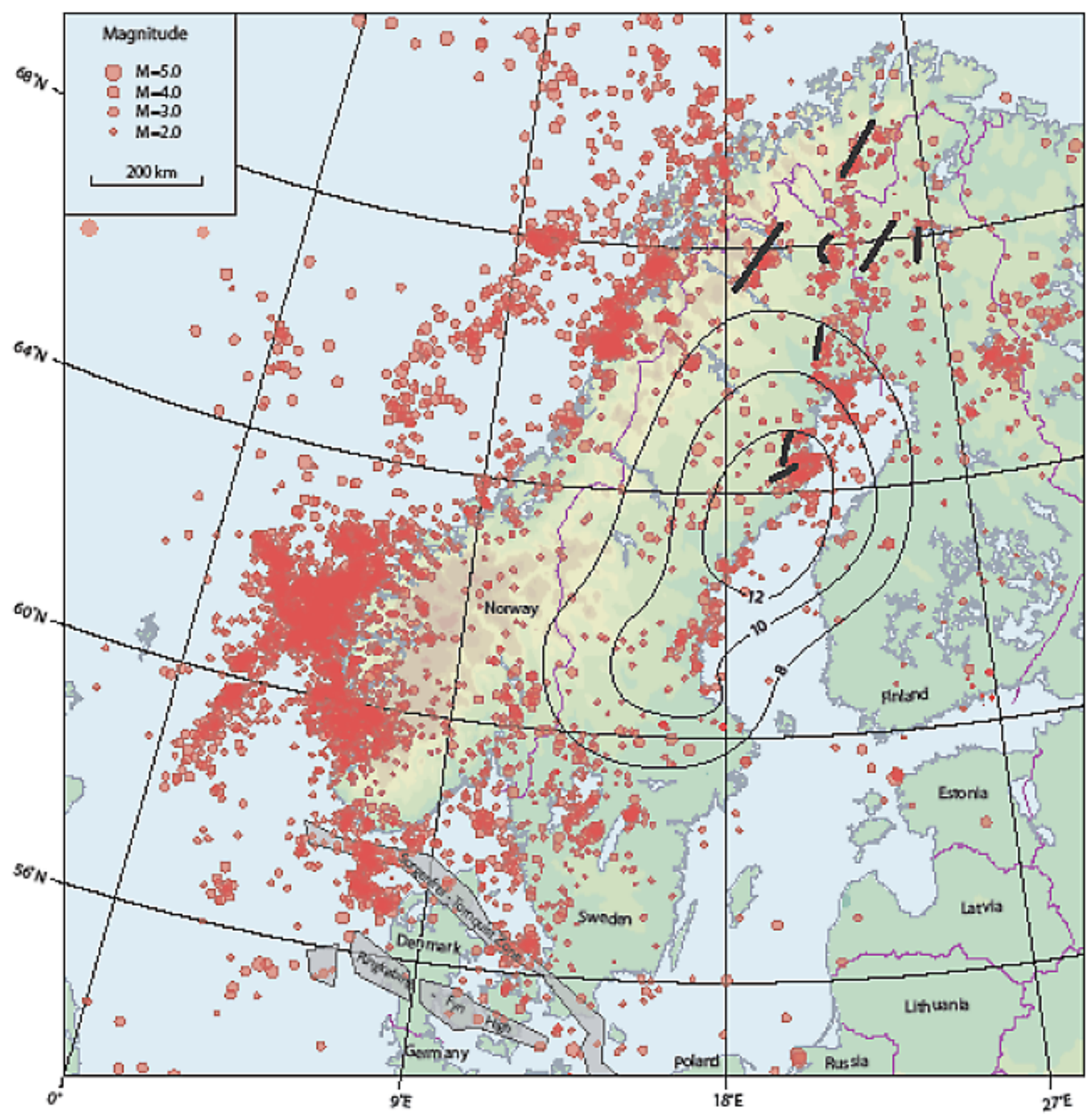

Fig. 1. Map of the earthquake geography in Scandinavia covering the years from January 1970 to December 2004. Earthquakes in the Danish area are extracted from the GEUS earthquake catalogue and earthquakes located outside this area are extracted from the Scandinavian catalogue from Helsinki University. The earthquake magnitude scale is given in the upper left corner. Contour lines show uplift in millimetres per year. Very thick black lines show the large postglacial faults of age close to $9000 \mathrm{yr}$ (Lagerbäck, 1991). Updated earthquake files for Denmark are available in home page http://www.geus.dk/ under seismology, and for the rest of Scandinavia in home page http://www. seismo.helsinki.fi/. From Gregersen and Voss (2009).

2012; Hansen et al., 2011) as well as from geological sources (Mertz, 1924; Paasse, 1996; Christensen, 2001). These maps all show a very regular pattern in the area, with the exception of a line across southern Denmark introduced by Hansen et al. (2011), which will be treated later in this paper as claim 3. The most complete geodetic map, that by Knudsen et al. (2012), has been chosen as reference for the locations of the treated irregularities (Fig. 3). It takes into account permanent GPS, three campaigns of precise levelling over the last hundred years as well as ten sea level stations in the area.

\subsection{Claim 1 - Carlsberg fault in the Copenhagen area}

This fault is one of the most significant in the Copenhagen area (e.g. Rosenkrantz, 1937; Nielsen and Thybo, 2004; 

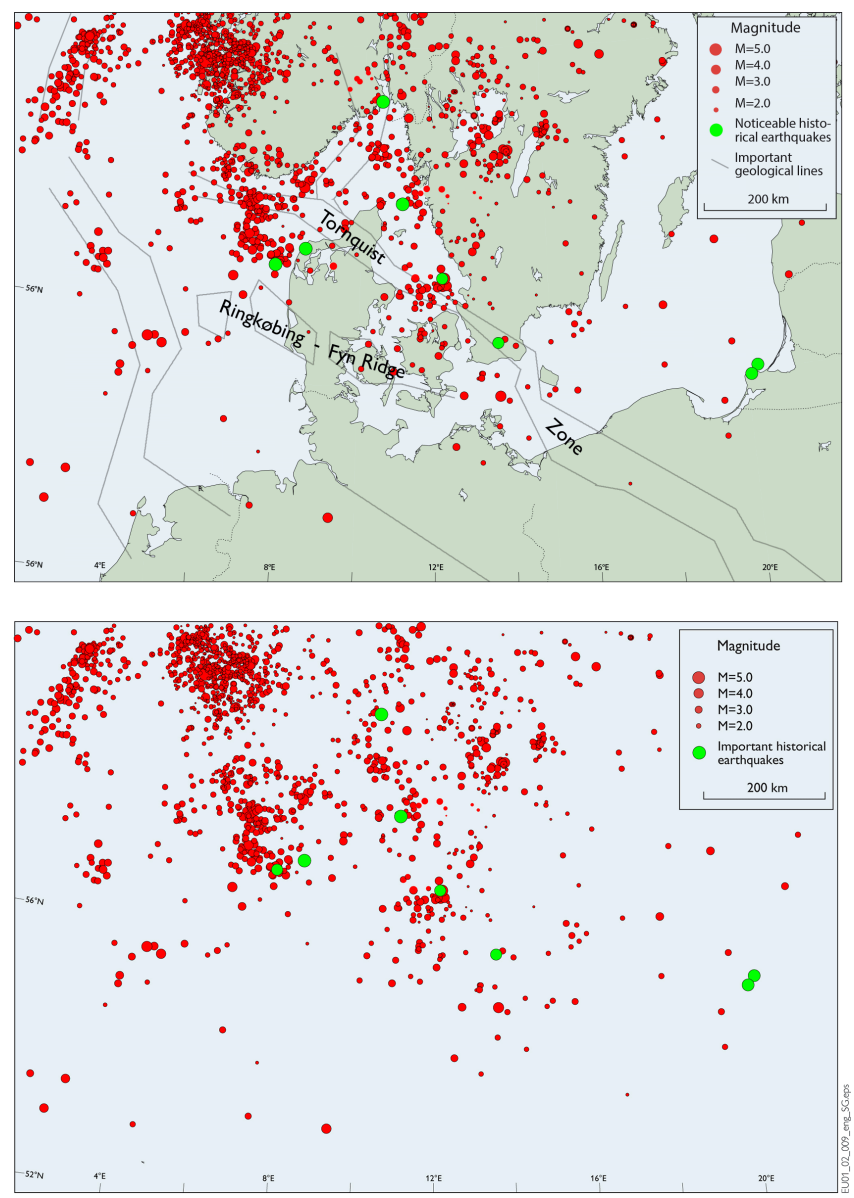

Fig. 2. Earthquake activity in and near Denmark without and with coast lines and geological zones. Red dots show modern welllocated earthquakes of the last $75 \mathrm{yr}$, and green dots show the most important relatively larger earthquakes in 1759, 1841, 1904, 1985, 2004, 2008, and 2010. The two maps cover the same area. Denmark is in the middle. Upper right hand corner is inside the Fennoscandian Shield, and in the lower left corner we are outside the shield. A gradual and irregular transition from the shield is noted. This can be termed the edge of the shield in relation to stresses and strains. From Gregersen et al. (2011).

Nielsen et al. 2005) (marked as Copenhagen on Fig. 3). It is part of the stepwise edge zone between the Fennoscandian shield and the deep sedimentary Norwegian-Danish Basin with depth to bedrock under Copenhagen 3-4 km. The Carlsberg fault runs NNW-SSE. It is only known well near the Carlsberg Brewery, to which the excellent water flow in a $500 \mathrm{~m}$ wide zone is very important. The vertical displacement of the near-surface Cretaceous limestone is about $90 \mathrm{~m}$. It is only known (Nielsen et al., 2005) to depths around $500 \mathrm{~m}$. Its length is only well confirmed to $10-12 \mathrm{~km}$ (Blem, 2002), or tentatively about $20 \mathrm{~km}$ (Jakobsen et al., 2002). The fault trace on the surface has been claimed observed through extensive cracking of house walls (B. Larsen, personal communication, 2009; O. Winther Christensen, personal communi-

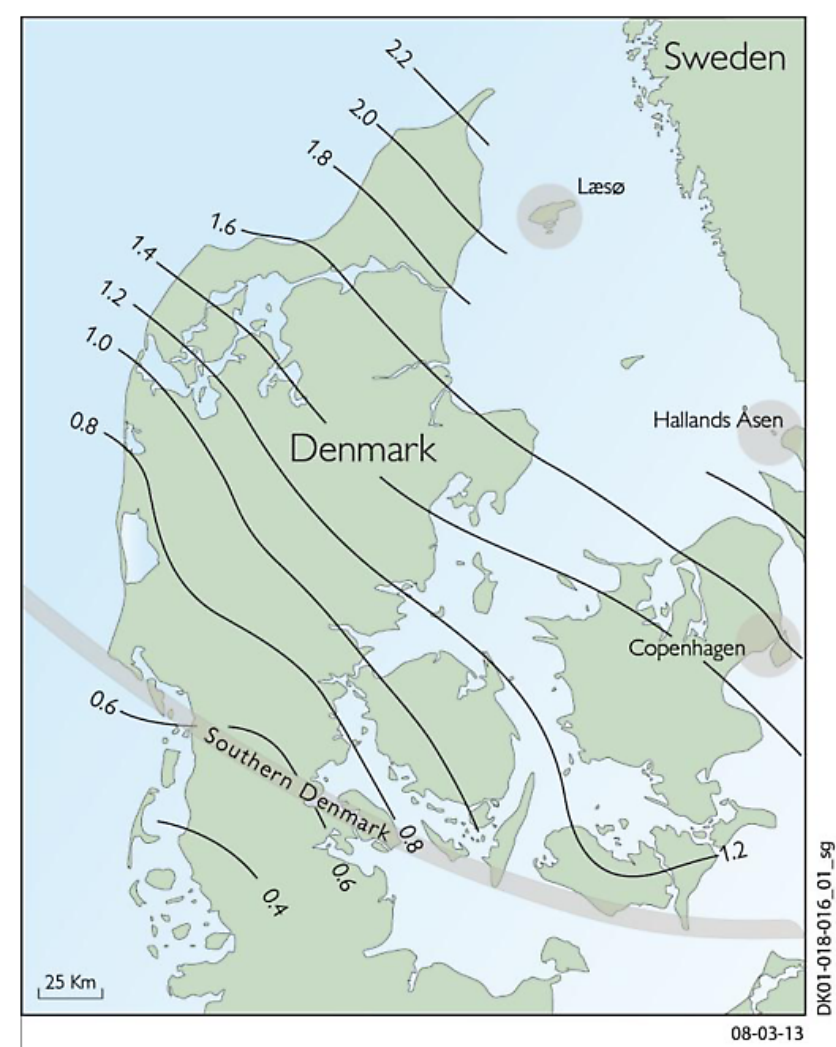

Fig. 3. Modern geodetic map (from Knudsen et al., 2012) with postglacial uplift in centimetres per year. Based on GPS, levelling and sea level stations. Four treated claims of earthquakes or other irregularities shown by grey shading.

cation, 1990s; Ovesen et al., 2002; L. Nielsen, personal communication, 2009). A very basic remark in assessing these observations is that a comparison with the surroundings is necessary. And this comparison has not been done. Motion on the fault stands as a suggestion, not as a result, and the alternative suggestion that irregularities are caused by differential settling of the loose upper sediments is more probable. A project with satellite radar scanning will as time goes have a chance to localize patterns of surface motion (Jakobsen et al., 2013). Tentatively the Carlsberg fault is pointed out over a length of $25 \mathrm{~km}$. Discussions on causes besides water pumping can be expected.

As seen in Fig. 2, the fault is not active with small earthquakes. It has been suggested by Rosenkrantz $(1934,1937)$ that the larger-than-usual earthquake which shook Copenhagen in 1930 can possibly be ascribed to this fault. Assessing this today, knowing the large uncertainties of earthquake locations in this area at that time, one must conclude that it could just as well be on another fault, easily ten kilometres away, and no indication has been observed for the choice.

The Carlsberg fault has also been held responsible for misfits in the Danish geodetic systems. The basis of the distance measuring system on the island Amager in Copenhagen 
has been described as deformed (Sand and Madsen, 1916; Ovesen et al., 2002). A large difference of $51 \mathrm{~mm}$ was reported between 1838 and 1911 of the basis line length of $2.7 \mathrm{~km}$. The more probable explanation of this (M. Aarestrup, personal communication, 1991; K. Engsager, personal communication, 2009) is near-surface sediment motion of one of the end points by temperature effects, especially freezing and thawing, toward which modern geodesists protect their measurements by relying on a group of separated points at each end rather than just one vulnerable point. Comparisons to basis length measurements north-west of Copenhagen show standard errors in the old data, so large that the length change turns out to be insignificant (Karsten Engsager, personal communication 2010). Support for a conclusion on stable length of the basis is that the 1838 measurement stands alone, while the 1911 basis length has been confirmed with standard errors $3 \mathrm{~mm}$ in 1933, 1934 as well as 1980 and 1993 (O. B. Andersen, personal communication, 1993), i.e. before and after the 1930 earthquake.

Also another basic distance in Amager (in Danish called prøvebane, trial distance) has been reported deformed (e.g. Ovesen et al. 2002). For this the geodetic problem has been observationally identified as the above-mentioned end point trouble. One of the ends is sloping strangely, so the end must have been disturbed by winter freezing and thawing (Karsten Engsager, personal communication 2009). Recently doubt has been presented whether the extension southwards of the Carlsberg fault actually crosses the geodetic lines (Ovesen et al. 2002).

In a paper on the levelling in the area of Copenhagen, Mark and Jensen (1982) have the following conclusion for the period between the 1940s and the 1970s: "An adjustment of the vertical displacements shows a tilting about twice as big as the one you know for Denmark as a whole, but the direction of the isolines is about the same. [...]Possible displacements in connection with the so-called Carlsberg fault can't be recognized in the results, but maybe some systematical displacement in Amager can be explained by the graben-structure in the area between the Carlsberg fault and the Svanemølle fault."

The assessment of the above discussion will have to conclude that the Carlsberg fault is probably responsible neither for displacements in earthquakes nor for geodetic reference line problems. There is no reason to believe that the Carlsberg fault is active based on the presented observations as these can easily be explained by alternative phenomena in a non-seismic area. In the similar Norwegian evaluation by Olesen et al. (2004) this would be classified as E, very unlikely to be neotectonics.

\subsection{Claim 2 - The island Læsø in the Kattegat Sea}

Hansen (1977, 1980, 1986a, b, 1994, 1995) and Bahnson (1986) have made geological investigations of sand deposits of ages less than $7000 \mathrm{yr}$ in Læs $\varnothing$ and found indications of a large fault of vertical displacement of $4 \mathrm{~m}$, from the surface to a depth of a few kilometres, and for an unknown length, which can at most be about $10 \mathrm{~km}$ in the terrain as it is. An earthquake has been proposed although no other indicators of earthquakes have been identified. The present assessment evaluates how this fault together with other indicators of postglacial movement fits into the tectonic setting close to the Sorgenfrei-Tornquist Zone.

In the 1980s the seismicity of the area was only marginally known (e.g. Lehmann, 1956; Gregersen, 1979), but tectonic activity was assumed by Bahnson (1986) and Hansen (1986a, b) with reference to structural studies showing many steep old faults (e.g. Baartman 1975). It was argued (Hansen, 1977; Bahnson, 1986) that Læsø does not fit in the postglacial uplift pattern of the neighboring Kattegat coasts. In a later paper this argument (Hansen 1994) was modified to: "Strangely enough the oldest beach line on Læs $\varnothing[\ldots]$ is at the same height as by Frederikshavn." How well the uplift curves of the highest beach lines in Læsø fit into the surroundings has later been illustrated by Christensen (2001) and quoted by Gregersen and Voss (2012).

Now assessing the Læsø observations 25 years later, we have more data on the region, both on the scale of Kattegat and for Scandinavia, and for other intraplate regions. This has changed the interpretation and understanding of the Læs $\emptyset$ case. The question earlier was whether Læs $\varnothing$ would fit into its assumed active surroundings. The question is now whether Læsø fits into its quiet, regular uplift surroundings. A review of the most significant arguments gives the following results:

1. As mentioned the maximum uplift of Læs $\varnothing$ since the regional flooding after the Ice Age fits nicely into the regional picture. That the island of Læsø should have subsided $4 \mathrm{~m}$ and then uplifted the same number of metres within several thousands of years is improbable, since the effects of such an event would be recognisable in neighboring coasts, where nothing is observed. And even more improbable, subsidence and uplift several times as suggested in the book by Hansen (1994) is not a possibility.

2. The alternation between transgressions and regressions in a time interval of several thousand years right after the Litorina Sea transgression is found similar in other locations of the Kattegat area as referred to in the overview paper by Noe-Nygård (2006) as well as that by Christensen (2001) and by Bjørnsen et al. (2008). The phenomenon is called the Litorina transgressions (Christensen, 1995). The last one ended 4000-5000 yr ago.

3. The paper by Baartman (1975) spoke about structural differences. The reference does not give any argument on recent activity. The structural steps and faults are confirmed by the later projects EUGENOS (EUGENO-S Working Group, 1989) and Tor 
(e.g. Gregersen et al. 2009). But as an argument concerning recently active faulting, the reference is contradicted by recent evaluations of the earthquake activity (Figs. 1 and 2) (e.g. Gregersen et al. 1995 and 1998).

4. A curve showing changes of tilting of successive beach terraces was presented by Hansen (1980). When the slopes were calculated no evaluation was made of uncertainties (Hansen, 1980). The slopes were based on heights, averaged over 10-15 individual height measurements within a spread of approximately one metre. This one metre can be taken as a rough estimate of four times the standard error. The present assessment extends the data handling to take into account this estimated standard error of a quarter of a metre. This means intoducing standard errors of the slopes, over distances smaller than $5 \mathrm{~km}$, at least as large as shown in Fig. 4, the basis of which is identical to Fig. 5 of Hansen (1980). It is here obvious that the tilting argument has become non-significant. The observed differences and the standard errors are of the same size, as shown in Fig. 4 of the present paper. The zigzag line of Hansen (1980) goes through the average values of the slopes. But the data may as well be explained by the thick straight line, that is within the belt of intervals determined by averages plus/minus one standard error. So the present assessment concludes that the differences in average slopes can not be used as an argument for discontinuous and occasionally reverse tilting. The data agree as well with steady uplift and tilting.

The errors mentioned above are directly concerned with the old data of Hansen (1980), which were used to show tilting of the beach terraces with respect to horizontal water level. But it will also apply to modern data, which is now available for Læs $\varnothing$. The same size of standard errors in the use of geological markers for slope measurements and for height measurements with respect to water level, are found in recent work by Nielsen and Clemmensen (2009). They observe similar large measurement scatter in modern data on Anholt, in the Kattegat Sea. In addition one must take into account that the physical circumstances of ocean currents and stormy weather influence the slopes, so these observations in Fig. 4 can not give an argument for oscillating tectonic tilting by themselves.

5. An almost vertical fault displacement in the sediments of approx. $4 \mathrm{~m}$, as said by Hansen (1986a, b), can be caused by displacement of various blocks in Læsø. The location of the fault is presented as a coastal cliff at the time of development, and coastal cliffs experience sliding by irregular erosion and gravity. The southern part of Læs $\emptyset$ must have experienced a sediment slide along the observed fault, either fast or slow.

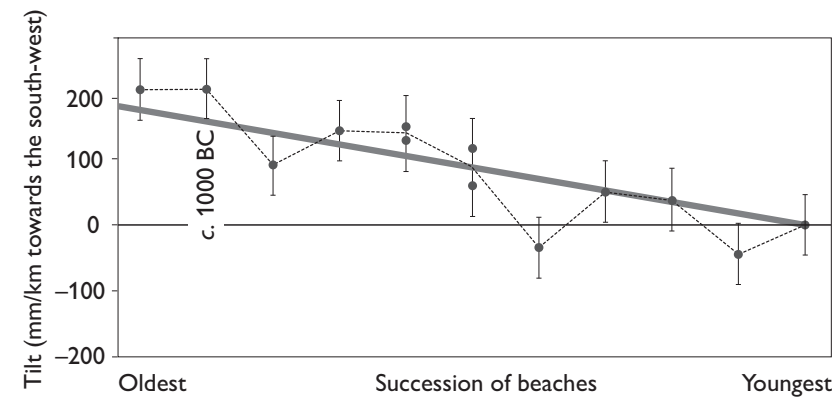

Fig. 4. Slopes of successive beach terraces of diminishing age to the right, with estimated standard errors. When standard errors are introduced in this Fig. 5 of Hansen (1980) it is obvious that abrupt changes of slopes are not significant. The slope readings are just as well explained by a steady change of slopes, approximated by the thick sloping line generally inside one standard error and certainly within two standard errors.

Sediment cliff slides are more probable in Læs $\varnothing$ than an earthquake, for which there is no other evidence in this aseismic area.

A whale in a height of $4.5 \mathrm{~m}$, of age approx. $3000 \mathrm{yr}$ as well as other dates have to fit into the regional frame. It may well show that the part of the island on which the whale rests did not follow the steady uplift of the oldest part of the island. A slide in a coastal cliff is naturally of great significance to the detailed geological description of Læs $\varnothing$, but of no significance to the tectonic evolution of the greater Kattegat region. The present topography is convincingly a succession of coastal terraces, which display a recent geological evolution explained in great detail by Hansen (1977, 1980, 1986a, b, 1994 and 1995) and followed up in recent further investigations (Hansen et al., 2011).

The present assessment of all of the old and new arguments concludes that the bedrock subsurface below Læs $\emptyset$ has been uplifted just as the rest of the Kattegat region, regularly or with minor irregularities. This means that there was no Læsø earthquake 4000-5000 yr ago. In the classification used by Olesen et al (2004) this means class E, very unlikely to be neotectonics. The lower parts of Læs $\emptyset$ with many welldocumented beach terraces have their own exciting development history (e.g. Hansen 1994; Hansen et al., 2011), best explained by regular postglacial uplift together with coastal development by water currents and weather, which is beyond the scope of this paper.

\subsection{Claim 3 - Line across southern Denmark}

A new map has introduced a hypothetical irregularity line called southern Denmark in Fig. 3. It is based on the geodetic/oceanographic data of water level stations of the last $100 \mathrm{yr}$ (Hansen et al., 2011). It includes a few more water level stations in the southern part than in Fig. 3, but is without 


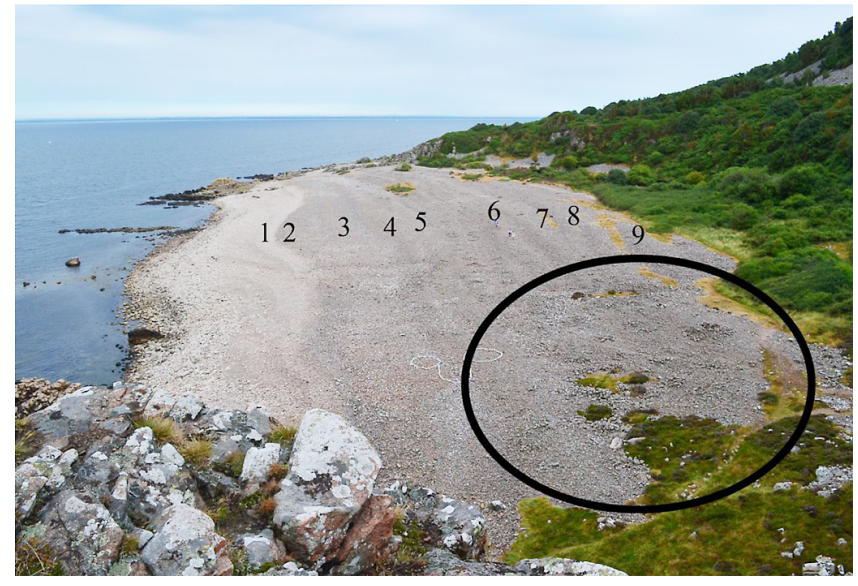

Fig. 5. Numbered beach ridges on Hallandsaasen seen from above. A major earth slide in the ringed area in the lower right side of the picture covers the older beach ridges (6-9) but not the younger ones (1-5). The view as seen during the field trip. The photograph is taken by the Russian seismologist Olga Pavlenko. Numbering is from Mörner (2003).

GPS and levelling, which in Fig. 3 supplemented the water level data. Instead of accepting irregularities in a few stations in southern Denmark as caused by weather and ocean currents, Hansen et al. (2011) focus arbitrarily on bedrock differences that show no motion in the seismological data or in the geodetic levelling and GPS. The uplift picture of Fig. 3 is more representative of the full data set, which does not have a discontinuity in southern Denmark. The claim can be classified by E in the classification used by Olesen et al. (2004), very unlikely to be neotectonics

South of Læsø in the Kattegat Sea (i.e. south of Claim 3 and north-west of Claim 4), the earthquake activity is interpreted from seismology (Gregersen et al., 1998). The seismicity picture as presented in Figs. 1 and 2 shows a concentration of earthquakes in a short part of the SorgenfreiTornquist Zone, where the zone changes character (e.g. Graversen 2009). This has been described by Arvidsson et al. (1991), Gregersen et al. (1996) and Jensen et al. (2002) as connected to confirmed recently active basement faults. Here there is potential for earthquakes of magnitudes as large as around 5. This is not far from Hallandsaasen (Fig. 3). Does it mean that the claim of postglacial earthquakes there is supported?

\subsection{Claim 4 - West coast of Sweden}

Several locations on the Swedish west coast have been mentioned as postglacial earthquake sites by Mörner (2003, 2009). Signs of geological movement in these locations are variations in postglacial uplift of beach lines, faulting and rock deformation in a few cases, and in many incidences rock slides and liquefaction in several stratigraphic layers. In several places liquefaction deformations have been observed and

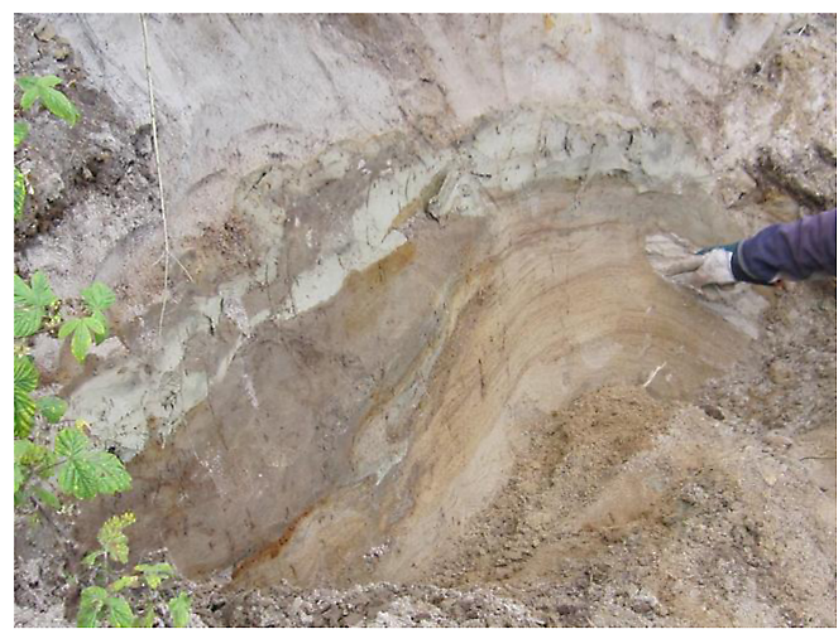

Fig. 6. Seismite? Disturbed water-filled sediment. Liquefaction. Photo by Soren Gregersen.

in some also signs of tsunami disturbances of the sediments. The evidence for earthquake interpretation is not as overwhelming as in northern Sweden in the layers from the end of the Ice Age (e.g. Lagerbäck, 1991), but it seemed worthwhile investigating the claims of postglacial earthquakes by Mörner $(2003,2009)$. A field trip to Hallandsaasen of 12 international seismologists was carried out on 27 July 2013. Nils-Axel Mörner added excellent educational details to his publications (Mörner, 2003, 2009). Figure 5 is exactly like one from Mörner (2003). The view, as seen during the field trip, convinces that a rock slide has disturbed the metre high steps of the numbered beach ridges 6 to 9 . The following pictures (Figs. 6 and 7) were taken of disturbances of dated water filled sediments (called seismites) and shattered rocks.

The field trip has given the evaluation that the signs shown of palaeo-earthquakes each could be caused by earthquake shaking, or by its own individual other cause. Misfit of beach lines in neighboring locations $400 \mathrm{~m}$ from each other could have been caused by slow non-earthquake motion or different sea wave and current systems. Talus falls and slides could occur without a starting earthquake. Liquefaction disturbance of sediment layers could be caused by water escape or slumping or bending of layers. Shattering of exposed bedrock could be caused by weather and climate, and tsunami signs in sediments are indications of disturbances, which could happen by non-earthquake slides as well as by earthquakes. Together one is left with a choice in the evaluation between coincidences or common cause: earthquake. The field trip convinced the participating seismologists that the claimed signs of earthquakes must be seriously taken into account.

Into the interpretation must go the overall pattern of gradual uplift of the whole region, into which only small irregularities fit. And when this is seen in connection with the drastic fall-off of stresses since the Ice Age (e.g. Gregersen and Voss, 2009), the present assessment results in a category D of 


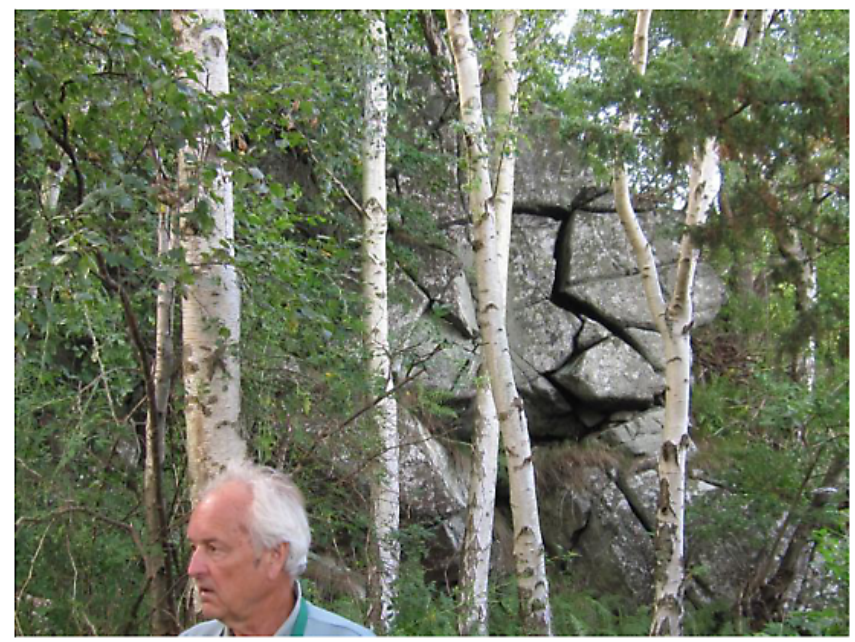

Fig. 7. Bedrock cliffs strongly fractured and moved by shaking or weather changes. Nils-Axel Mörner explaining the phenomenon. Photo by Soren Gregersen.

the classification used by Olesen et al. (2004), which means probably not neotectonics, because coincidence is the most probable explanation.

In Skåne, southern Sweden repeated GPS measurements by Pan et al. (1999) have indicated differences between the two sides of the Tornquist Zone. These measurements are not considered statistically significant by our Swedish geodesist colleagues, who now use permanent GPS stations. A small, seldom earthquake happened in Skåne 16 December 2008 on the north-eastern flank of the Tornquist Zone (Fig. 2). This earthquake was as small as the others that have been located in the surrounding region (Voss et al., 2009).

\section{Conclusions}

The overall conclusion is that a number of reports, claiming geologic or geodetic recent irregularity in and near Denmark, have been found and discussed. It has been identified that a supplementary geological comparison of the uplift phenomenon with identical counting of beach lines and identical age determinations across the Kattegat between the claims in Denmark and that in south-western Sweden will be worthwhile. The assessment has uncovered no signs of geologic recent faulting or recent crustal deformations, which contradict the seismicity picture of minor earthquake activity, up to a magnitude just below 6 . The earthquake zones are those found by historical and instrumental-seismological investigations in the seas around Denmark as illustrated in Figs. 1 and 2 . The activity is geographically spread out. Not even the very significant Sorgenfrei-Tornquist Zone is an irregularity zone with earthquakes.
Acknowledgements. We appreciate many good discussions with our colleagues Jens Morten Hansen, Peter Johannesen, Lars Henrik Nielsen, Tine B. Larsen, Tanni J. Abramovitz, Abbas Khan, Karsten Engsager, Holger Lykke-Andersen, Torben Bidstrup, Birger Larsen, Jørgen Leth, Lars Nielsen, Henrik Olsen, Hans Thybo and Lars B. Clemmensen.

Special Issue: "Lithosphere-cryosphere interactions"

Edited by: M. Poutanen, B. Vermeesen, V. Klemann, and C. Pascal

\section{References}

Ågren, J. and Svensson, R.: Postglacial Land Uplift Model and System Definition for the new Swedish Height System RH 2000, Reports in Geodesy and Geographical Information System Rapportserie, LMV-Rapport 2007:4, Lantmäteriet, Gävle, Sweden, 2007.

Arvidsson, R., Gregersen, S., Kulhanek, O., and Wahlström, R.: Recent Kattegat earthquakes - evidence of active intraplate tectonics in southern Scandinavia, Phys. Earth Plan. Int., 67, 275-287, 1991..

Baartman, H.: Some results of the interpretation of seismic data in the Kattegat, S. Øresund, and Østers $\varnothing$, W., in: Contributions to the interpretation of the Fennoscandian Border Zone, edited by: Baartman, H. and Christensen, O. B., Danmarks Geologiske Undersøgelse, 102, 6-20, 1975.

Bahnson, H.: Lithologisk undersøgelse af materiale fra seks boringer på Læs $\varnothing$, Danmarks Geologiske Undersøgelse serie D, 6, 7-27, 1986.

Bjørnsen, M., Clemmensen, L. B., Murray, A., and Pedersen, K.: New evidence of the Littorina transgressions in the Kattegat Optically stimulated luminescence dating of a beach ridge system on Anholt, Denmark, Boreas, 37, 157-168, 2008.

Blem, H.: Carlsberg Fault - History, location and importance (in Danish), B. Danish Geotechnic. Soc., 19, 61-82, 2002.

Bungum, H., Alsaker, A., Kvamme, L. B., and Hansen, R. A.: Seismicity and seismotectonics of Norway and nearby continental shelf areas, J. Geophys. Res., 96, 2249-2265, 1991.

Bungun, H., Pascal, C., Olesen, O., Lindholm, C., Vestøl, O., and Gibbons, S.: To what extent is the present seismicity of Norway driven by postglacial rebound?, J. Geol. Soc. London, 167, 373384, 2010.

Christensen, C.: The Litorina transgressions in Denmark, in: Man and sea in the Mesolithic, edited by: Fischer, A., Oxbow Monograph, Oxford, 53, 15-22, 1995.

Christensen, C.: Coastal settlement and sea level change in the Stone Age, in: Jensen, O. L., Soerensen, S. A., and Hansen, K. M., Denmarks Hunting Stone Age - status and perspectives, Hoersholm Egns Museum 2001, 183-193, 2001.

EUGENOS Working Group: Crustal structure and tectonic evolution of the transition between the Baltic Shield and the North German Caledonides (the EUGENOS Project), Tectonophysics, 150, 253-348, 1988.

Graversen, O.: Structural analysis of superposed fault systems of the Bornholm horst block, Tornquist Zone, Denmark, Bull. Geol. Soc. Denmark, 57, 25-49, 2009.

Gregersen, S.: Earthquakes in the Skagerrak recorded at small distances. Bulletin of the Danish Geological Society, 28, 5-9, 1979. 
Gregersen, S.: Earthquake activity in the North Sea area, Dansk Geologisk Forening, Årsskrift for 1981, 157-159, 1982 (in Danish).

Gregersen, S.: Crustal stress in northern Europe, in: Proceedings of the VI workshop on the European Geotraverse Project, edted by: Freeman, R. and Müller, S., ESF Strasbourg, 357-360, 1990.

Gregersen, S.: Crustal stress regime in Fennoscandia from focal mechanisms, J. Geophys. Res., 97, 11821-11827, 1992.

Gregersen, S.: Earthquakes and change of stress since the ice age in Scandinavia, Bull. Geol. Soc. Denmark, 49, 73-78, 2002.

Gregersen, S. and Basham, P. W. (Eds.): Earthquakes at North Atlantic Passive Margins: Neotectonics and Postglacial Rebound, Kluwer Academic Press, 716 pp., 1989.

Gregersen, S. and working group on recent crustal movements around the Tornquist Zone: Recent crustal movements and earthquakes in the area of the Tornquist Zone, Studia Geophysica et geodaetica, 39, 257-261, 1995.

Gregersen, S. and Voss, P.: Stress change over short geological time: case of Scandinavia over 9000 years since the Ice Age, in: Paleoseismology: Historical and prehistorical records of earthquake ground effects for seismic hazard assessment, edited by: Reicherter, K., Michetti, A. M., and Silva Barroso, P. G., Geological Society of London, Special Publications, 316, 173-178, 2009.

Gregersen, S. and Voss, P.: Irregularities in Scandinavian postglacial uplift/subsidence in time scales tens, hundreds, thousands of years, J. Geodyn., 50, 27-31, 2010.

Gregersen, S. and Voss, P. H.: Efforts to include geological and geodetic observations in the assessment of earthquake activity in Denmark, Geological Survey of Denmark and Greenland Bulletin, 26, 41-44, 2012.

Gregersen, S., Leth, J., Lind, G., and Lykke-Andersen, H.: Earthquake activity and its relationship with geologically recent motion in Denmark, Tectonophysics, 257, 265-273, 1996.

Gregersen, S., Hjelme, J., and Hjortenberg, E.: Earthquakes in Denmark, Bull. Geological Soc. Denmark, 44, 115-127, 1998.

Gregersen, S., Wiejacz, P., Dębski, W., Domanski, B., Assinovskaya, B., Guterch, B., Mäntyniemi, P., Nikulin, G., Pacesa, A., Puura, V., Aronov,A. G., Aronova, T. I., Grünthal, G., Husebye, E. S., and Sliaupa, S.: The exceptional earthquakes in Kaliningrad District, Russia on September 21, 2004, Phys. Earth Planet. Inter., 164, 63-74, 2007.

Gregersen, S., Voss, P., Nielsen, L. V., Achauer, U., Busche, H., Rabbbel, W., and Shomali, Z. H.: Uniqueness of modelling results from teleseismic P-wave tomography in Project Tor. Tectonophysics, 481, 99-107, doi:10.1016/j.tecto.2009.01.020, 2009.

Gregersen, S., Larsen, T. B., and Voss, P. H.: Earthquakes on the Sorgenfrei-Tornquist Zone, Geoviden 2011 no. 1. GEUS Copenhagen, 2011 (in Danish).

Grünthal, G., Stromeyer, D., Wylegalla, K., Kind, R., Wahlström, R., Yuan, X., and Bock, G.: The Mw 3.1-4.7 earthquakes in the southern Baltic Sea and adjacent areas in 2000, 2001 and 2004, J. Seismology, 12, 413-429, doi:10.1007/s10950-008-9096-0, 2008.

Hansen, J. M.: Sedimentary history of the island Læs $\varnothing$, Denmark, Bull. Geol. Soc. Denmark, 26, 217-236, 1977.

Hansen, J. M.: Læsøs postglaciale udvikling i relation til den Fennoskandiske Randzone, Dansk Geologisk Forening, Årsskrift for 1979, 23-30, 1980.
Hansen, J. M.: Læsø: A result of fault displacements, earthquakes and level changes, Danmarks Geologiske Undersøgelse serie D, 6, 47-72, 1986a (in Danish).

Hansen J. M.: A prehistoric earthquake, Museumsforeningen for Læsø, Årbog for 1985, 17-23, 1986b (in Danish).

Hansen, J. M.: Læsø's evolution and landscapes - about the island that rocks and jumps, Danish Geological Survey, Geografforlaget, Brenderup, Denmark, 55 pp., 1994 (in Danish).

Hansen, J. M.: The appearance of an island, its beach development and vegetation evolution: Natural and human-made landscapes on Læs $\varnothing$, Geologisk Tidsskrift, 2, 1-74, 1995 (in Danish).

Hansen, J. M., Aagaard, T., and Binderup, M.: Absolute sea levels and isostatic changes of the eastern North Sea to central Baltic region during the last 900 years, Boreas, 41, 180-208, doi:10.1111/j.1502-3885.2011.00229.x, 2011.

Hicks, E. C., Bungum, H., and Lindholm, C. D.: Stress inversion of earthquake focal mechanism solutions from onshore and offshore Norway, Norsk Geol. Tidsskr., 80, 235-250, 2000.

Jakobsen, P. R., Fallesen, J., and Knudsen, C. Structures in the Copenhagen subsurface - folds, faults and cracks (in Danish), B. Danish Geotechnic. Soc., 19, 19-29, 2002.

Jakobsen, P. R., Wegmuller, U., Capes, R., and Pedersen, S. A. S.: Terrain subsidence detected by satellite radar scanning of the Copenhagen area, Denmark, and its relation to the tectonic framework, Geol. Surv. Den. Greenl., 26, 25-28, 2013.

Jensen, J. B., Petersen, K. S., Konradi, P., Kuijpers, A, Bennike, O., Lemke, W., and Endler, R.: Neotectonics, sea-level changes and biological evolution in the Fennoscandian Border Zone of the southern Kattegat Sea, Boreas, 31, 133-150, 2002.

Knudsen, P., Engsager, K. E., and Khan A. K.: Documentation of calculation of new uplift model 2011, Report from DTU-Space to the Danish Geodata-authority. Home page of DTU-Space, 2012 (in Danish).

Lagerbäck, R.: Late Quaternary faulting and paleoseismicity in northern Scandinavia, with particular reference to the Lansjärv area, northern Sweden. Geologiska Föreningens i Stockholm Förhandlinger, 112, 333-354, 1990.

Lagerbäck, R.: Seismically deformed sediments in the Lansjärv area, northern Sweden. SKB Technical Report 91-17, Svensk Kärnbränslehandtering AB, Stockholm, Sweden, 58 pp., 1991.

Lambeck, K., Purcell, A., Zhao, J., and Svensson, N.-O.: The Scandinavian Ice Sheet: from MIS 4 to the end of the Last Glacial Maximum, Boreas, 39, 410-435, doi:10.1111/j.15023885.2010.00140.x, 2010.

Lehmann, I.: Danish earthquakes, Meddelelser for Dansk Geologisk Forening, 13, 88-103, 1956 (in Danish).

Lindholm, C. D., Bungum, H., Hicks, E., and Villagran, M.: Crustal stress and tectonics in Norwegian regions determined from earthquake focal mechanisms, Geol. Soc. London, 167, 429-439, 2000.

Mark, A. N. and Jensen, J. E. K.: Level changes in Copenhagen, Landinspektøren, 12 pp., 1982.

Mertz, E. L.: Late and post-glacial height changes in Denmark, Danish Geological Survey (DGU) 2. række, 41, 50 pp., 1924 (in Danish).

Mörner, N.-A.: The Fennoscandian uplift and late Cenozoic geodynamics: Geological evidence, GeoJournal, 3, 287-318, 1979.

Mörner, N.-A.: Paleoseismicity of Sweden. A novel paradigm, JOFO Grafiska AB, Stockholm, 2003. 
Mörner, N.-A.: Late Holocene earthquake geology in Sweden, in: Paleoseismology: Historical and prehistorical records of earthquake ground effects for seismic hazard assessment, edited by: Reicherter, K., Michetti, A. M., and Silva Barroso, P. G., Geol. Soc. London, Special Publications, 316, 179-188, doi:10.1144/SP316.10, 2009.

Nielsen, L. and Clemmensen, L. B.: Sea-level markers identified in ground-penetrating radar data collected across a modern beach ridge system in a microtidal regime, Terra Nova, 21, 474-479, 2009.

Nielsen, L. and Thybo, H.: Location of the Carlsberg Fault zone from seismic controlled-source fan recordings, Geophys. Res. Lett., 31, L07621, doi:10.1029/2004GL019603, 2004.

Nielsen, L. Thybo, H., and Jørgensen, M. I.: Integrated seismic interpretation oft he Carlsberg Fault zone, Copenhagen, Denmark, Geophys. J. Int., 162, 461-478, 2005.

Noe-Nygård, N.: From Ice Age to Stone Age, in: The Nature of Denmark, Geology, Gyldendal, Copenhagen, 2006 (in Danish).

Olesen, O., Blikra, L. H., Braathen, A., Dehls, J. F., Olsen, L., Rise, L., Roberts, D., Riis, F., Faleide, J. I., and Anda, E.: Neotectonic deformation in Norway and its implications: a review, Norwegian J. Geol., 84, 3-34, 2004.

Olesen, O., Bungum, H., Dehls, J., Lindholm, C., Pascal, C., and Roberts, D.: Neotectonics, seismicity and contemporary stress field in Norway - mechanisms and implications, NGU Special Publication, 13, 143-172, 2012.

Ovesen, N. K., Blem, H., Gregersen, S., Møller, H. M. F., and Frederiksen, J. K.: Recent terrain-movements in Copenhagen, Bull. Danish Geotechn. Soc., 19, 183-192, 2002 (in Danish).

Pan, M., Sjöberg, L. E., Talbot, C.. and Asenjo, E.: GPS measurements of crustal deformation in Skåne, Sweden between 1989 and 1996, Geofys. Fören. Forhandl., 121, 67-72. 1999.

Pascal, C. and Cloetingh, S. A. P. L.: Gravitational potential stresses and stress field of passive continental margins: Insights from the south-Norway shelf, Earth Planet. Sc. Lett., 277, 464-473, 2009.
Poutanen, M., Dransch, D., Gregersen, S., Haubrock, S., Ivins, E. R., Klemann, V., Kozlovskaya, E., Kukkonen, I., Lund, B., Lunkka, J.-P., Milne, G., Müller, J., Pascal, C., Pettersen, B.-R., Scherneck, H.-G., Steffen, H., Vermeersen, B., and Wolf, D.: DynaQlim - Upper mantle dynamics and Quaternary climate in cratonic areas, in: New Frontiers in Integrated Solid Earth Sciences, edited by: Cloetingh, S. and Negendank, J., International Year of Planet Earth Book Series, Springer Verlag, 349-372, 2009.

Paasse, T.: A mathematical model of the shore level displacement in Fennoscandia, Swedish Nuclear Waste management Company (SKB) Technical report 96-24, Stockholm Sweden, 92 pp., 1996.

Rosenkrantz, A.: Remark considering a fault in the subsurface of southeastern Copenhagen, Bull. Geol. Soc. Denmark, 8, 407410, 1934 (in Danish).

Rosenkrantz, A.: Remarks on the Danian stratigraphy and tectonics on eastern Sealand, Bull. Geol. Soc. Denmark, 9, 199-212, 1937 (in Danish).

Sand, M. J. and Madsen, V. H. O.: New Basis measurements in Denmark. Den Danske Gradmaaling, Ny række, hefte 15, Copenhagen, 1916.

Vest $\varnothing 1$, O.: Determination of postglacial land uplift in Fennoscandia from levelling, tide-guages and continuous GPS stations using least squares collocation, J. Geodynamics, 80, 248-258, 2006.

Voss, P., Larsen, T. B. Ottemöller, L., and Gregersen, S.: Earthquake in southern Sweden wakes up Denmark on 16 December 2008, GEUS Review of Survey Activities (ROSA) 2008, 9-12, 2009.

Zoback, M. L.: First and second-order patterns of stress in the lithosphere: The World Stress Map Project, J. Geophys. Res., 97, 11703-11728, 1992.

Zoback, M. L., Zoback, M. D., Adams, J., Assumpcao, M., Bell, S., Bergmann, E. A., Bluemling, P., Brereton, N. R., Denham, D., Ding, J., Fuchs, K., Gay, N., Gregersen, S., Gupta, H. K., Gvishiani, A., Jacob, K., Klein, R., Knoll, P., Magee, M., Mercier, J. L., Müller, B. C., Paquin, C., Rajendran, K., Stephansson, O., Suarez, G., Suter, M., Udias, A., Xu, Z. H., and Zhizhin, M.: Global patterns of tectonic stress, Nature, 341, 291-298, 1989. 